\title{
The port of Leixões (Portugal): over 120 years of knowledge
}

Hugo Guedes Lopes CEng, BSc, MSc, PhD

Civil Engineer (Hydraulics) and Senior Officer, APDL - Port Authority of Douro, Leixões and Viana do Castelo, S.A., Leça da Palmeira, Portugal; Invited Adjunct Professor, Department of Geotechnical Engineering, School of Engineering (ISEP), Polytechnic of Porto, Porto, Portugal (corresponding author: hugo.lopes@apdl.pt)

\author{
Emílio Brògueira Dias CEng, BSC \\ Civil Engineer (Hydraulics) and Former President of APDL Board, APDL - \\ Port Authority of Douro, Leixões and Viana do Castelo, S.A., Leça da \\ Palmeira, Portugal
}

The port of Leixões was built in the nineteenth century as an alternative to the Douro port in North Portugal. Despite the importance of the Douro port in the fifteenth and sixteenth centuries (during the age of discoveries) and later in the eighteenth century with the port wine trade, it had several restrictions - namely, geomorphic and hydrodynamic features. The first studies of the new port of Leixões date back to the fifteenth century, but it was in the eighteenth century that a strong effort was made to deliver a viable alternative to the Douro port. Due to the magnitude of the work, it was considered one of the biggest engineering works of the nineteenth century. A diversity of structures are addressed, from vertical rock/concrete quay walls to piled quays and dolphins, pointing out the problems and describing the solutions. This work aims to describe the construction of the second most important port of Portugal, whose docks were totally excavated on the mouth of the River Leça, and its developments in over 120 years, focusing on the main geotechnical problems met and their mitigation. In fact, harbour geotechnics could learn from this outstanding engineering experience, and the Leixões port may contribute to that knowledge.

\section{Notation}

$C_{\mathrm{r}} \quad$ radial consolidation coefficient

$C_{\mathrm{v}} \quad$ vertical consolidation coefficient

$d \quad$ theoretical diameter of the drain used

$H \quad$ thickness of the compressible layer

$m_{\mathrm{v}} \quad$ volumetric compressibility coefficient

$T^{\prime} \quad$ time factor considering the consolidation system

$T_{\mathrm{v}} \quad$ time factor considering natural settlement

$t \quad$ time

$\Delta H \quad$ total settlement

$\Delta p \quad$ tension variation

\section{Introduction}

The north-west Iberian coastline is shaped by numerous rivers, inlets and bays. The shoreline has a coastal and maritime environment that is very dynamic, heterogeneous and mixed (e.g. Dias et al., 2000; Mota-Oliveira et al.. 1982; Pérez-Alberti et al., 2013; Pires et al., 2016; Veloso-Gomes, et al. 2004; and references therein). From a rocky shore or platforms to a varied environment, the region includes sandy beaches and coastal protection works (e.g. Mota-Oliveira et al., 2000; Pires et al., 2014, 2016; Veloso-Gomes and Taveira-Pinto, 2003). Besides, the role of the coastal erosion is a result of the dynamic nature of its coastal zones, anthropic interactions and influences, such as coastal interventions and littoral occupation, and of the effects of climate change (Coelho et al., 2009). For all that, keen and integrative studies for harbour and maritime geotechnics are essential (Ciria et al., 2007).

The port of Leixões is located in the mainland Portugal, in the north-west of the Iberian Peninsula, about $4 \mathrm{~km}$ to the north of the mouth of the River Douro (Porto and Gaia cities), facing the Atlantic Ocean. The port is surrounded by the municipalities of Leça da Palmeira to the north and Matosinhos to the south; it is also near the second largest city of Portugal, Porto.

The port of Leixões was constructed in the nineteenth century as an alternative to the Douro port in Porto (Alves and BrògueiraDias, 2001; Sousa and Alves, 2002). Regardless of the importance of the Douro port in the fifteenth and sixteenth centuries and later in the eighteenth century with the port wine trade, it had several restrictions, such as stream floods in the winter, a river mouth with strong currents and rocky bottom (with a maximum of $5 \mathrm{~m}$ depth) with a dynamic sandspit (Figure 1). As ships grew bigger, the entrance at the mouth of the Douro River became even more dangerous and risky, and so an alternative had to be found (Alves and Brògueira-Dias, 2001; Brògueira-Dias and Alves, 2010).

The first studies of the new port of Leixões dated from the fifteenth century, but it was in the eighteenth century that a strong effort was made to deliver a viable alternative to the Douro port (Figure 2). Due to the magnitude of the work, it was considered one of the major and emblematic engineering works of the nineteenth century, in Portugal (Brògueira-Dias and Alves, 2010) (Figure 3).

The entrance of the River Douro and its sandspit retreated more than $600 \mathrm{~m}$ in the past 150 years, which led to more than 30 years of studies to define the solution, built in the beginning of the twenty-first century, that aimed to stabilise the mouth of the river and contribute to the improvement in safety conditions on both riversides (Gomes et al., 2005; Veloso-Gomes et al., 2004). However, the low depth of the river entrance $(-5.0 \mathrm{~m})$ is still a 

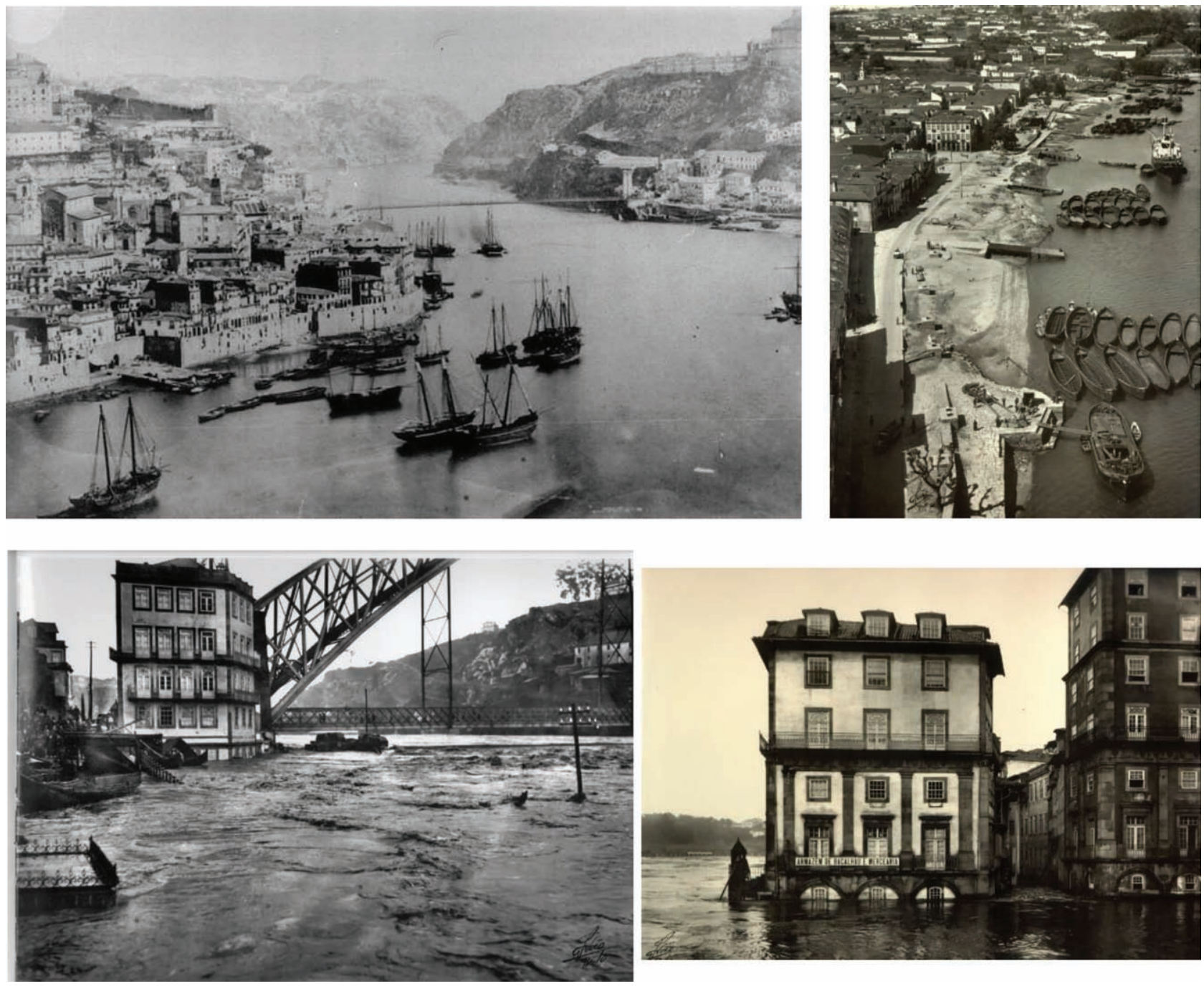

Figure 1. The port of Douro and river floods

limitation for larger vessels, confirming the good choice taken in the nineteenth century.

Since it was built, the port has endured numerous improvements, particularly the expansion towards the sea and the excavation of new docks inland, before 1936. In 1936, the port authority (nowadays the Port Authority of Douro, Leixões and Viana do Castelo (APDL)) decided to build outside the old port a kind of protective structure - a largely submerged breakwater with a length of approximately $1000 \mathrm{~m}$, to serve as protection of the entrance against storms. With the construction of the submerged breakwater, the operational conditions inside the port improved considerably. However, in order to protect the oil terminal from the direct action of waves that overtopped the submerged breakwater previously built, this structural amenity was raised in 1969. The solution as-built consisted of a $40 \mathrm{t}$ tetrapod slope, built over the $90 \mathrm{t}$ blocks of the submerged breakwater, and a concrete superstructure to protect the oil terminal access platform against overtopping. The initial submerged breakwater had two main objectives: to create the proper conditions for port operations and to increase the safety of the ships inside the port basin. As a complement, the access conditions to the port had to be improved in order to increase the number of days of the year on which the ships could enter safely. However, the stability of the tetrapods, which was satisfactory in the model tests, early appeared less effective in the prototype. Apart from the fractures and/or the sliding of tetrapods almost along all the length of the breakwater, there were two very vulnerable areas: the head of the breakwater and the oil terminal section. The damage was so significant that by the year of 1972, two years after the end of the construction, a recharge of 1000 tetrapods had been done (in the construction 2868 tetrapods were used). In the repair of the damages caused by the storms of 1973 and 1974, a total of 1010 tetrapods were placed. In the repair works, the reinforcement of the south limit of the breakwater was also included. The reinforcement consisted of abandoning the 


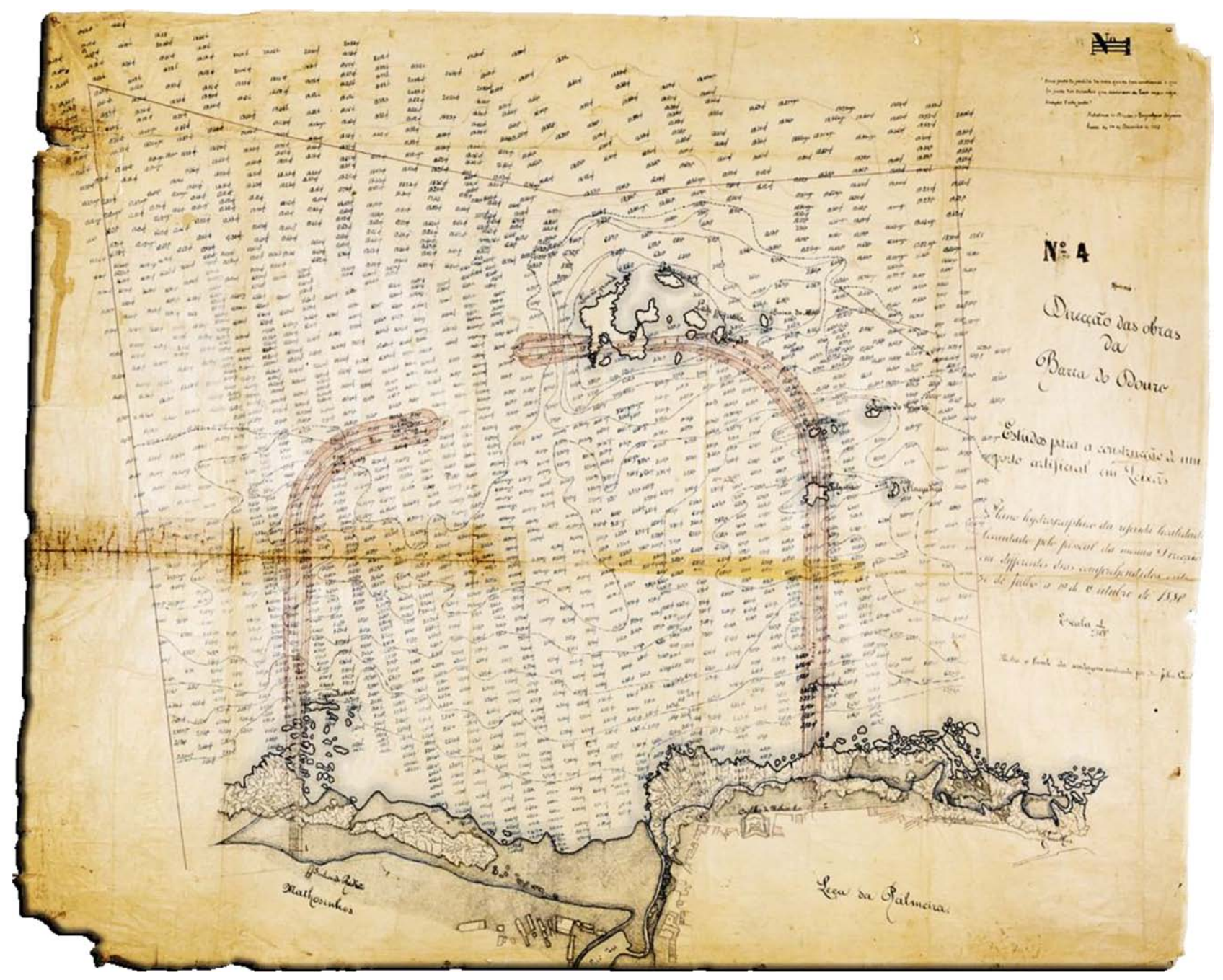

Figure 2. Layout of the port of Leixões breakwater

tetrapods, and replacing them, below the $+1.0 \mathrm{~m}$ Chart Datum level, by cubic blocks of $40 \mathrm{t}$. Above that level, a concrete steeped structure built 'in situ' was considered. The head of the breakwater appeared to be very vulnerable, and the damages were higher than what was expected. As a result, a detached breakwater was built in 1982 (details in the thesis by Lopes (2013)).

At present, the current mission of APDL is to manage the Douro, Leixões and Viana do Castelo ports and the inland waterway of the Douro River, undertaking their economic exploitation, conservation and development, including the powers assigned to the port authority.

\section{Key harbour geotechnic studies on the port of Leixões: construction, problems and rehabilitation}

The port of Leixões has undergone, during the past decades, several improvements, mostly the expansion inland with the excavation of new docks, the extension and raising of the original breakwater and the construction of a new submerged breakwater to protect the head of the breakwater (details in the publication by Lopes et al. (2013)). Furthermore, several studies were published in past years related to the Leixões port area and related geotechnic issues (e.g. APDL, 1987; Brògueira-Dias, 1992; Brògueira-Dias and Coutinho, 1998; Lopes et al., 2013; Pinto et al., 2013; Rosa-Santos and Taveira-Pinto, 2013; Veloso-Gomes et al., 2009; and references therein).

\section{Dock number 1}

Dock number 1 was constructed between 1932 and 1940 (Figure 4). This dock was totally excavated onshore, upstream the River Leça, which had to be deviated to allow the construction of the dock. The deviation was guaranteed by two branches, one to the north with a twin aqueduct and another to the south with an artificial channel.

Previous to the construction, a geotechnical survey was made (using Degousé rotation and manual percussion) using an $80 \times 180 \mathrm{~m}$ array. 
The port of Leixões (Portugal): over 120 years of knowledge

Lopes and Dias
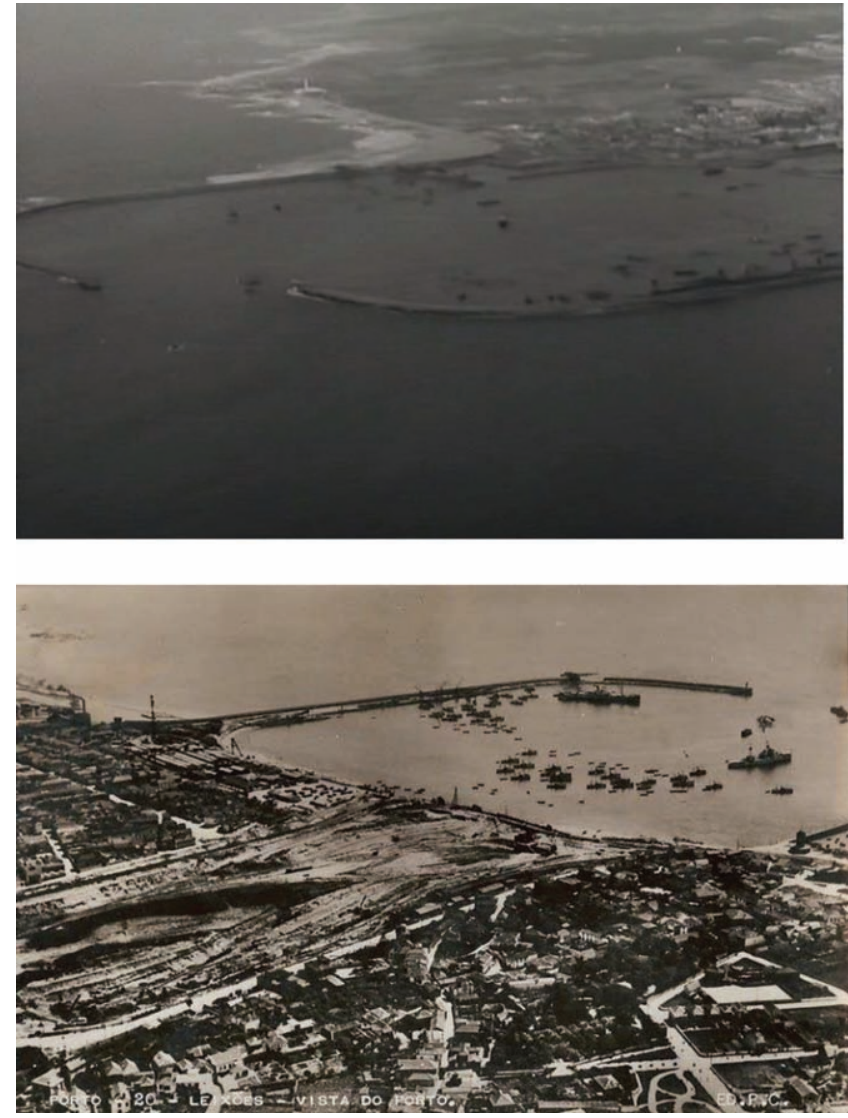

Figure 3. The port of Leixões at the beginning of the twentieth century

Generally, the bedrock was detected at $-10.0 \mathrm{~m}$ ZHL (Leixões chart datum). However, there were two regions, one in the north-east dock with approximately $100 \mathrm{~m}$ and the other with $80 \mathrm{~m}$ in the south-west dock, where the bedrock was only at $-20.0 \mathrm{~m}$ ZHL.

Two different technical solutions were defined for the quay wall: solution 1, a continuous gravity wall that was implemented whenever the bedrock was above $-11.0 \mathrm{~m} \mathrm{ZHL}$, and solution 2, a pier structure with arches founded at the bedrock, using the Havage method (Figure 5).

However, in the 1970s, solution 2 started to evidence some fragilities. The arches entered into disrepair, and the main causes were not completely elucidated, but bad/poor mortar behaviour along with ground movement bellow the pillars was pointed out at that time.

The rehabilitation of both failures, in the north and in the south dock, was designed as presented in Figure 6, with a sheet pile curtain (BZVR) and anchors built on the sea side of the old quay.

In the 1990 s, the continuous gravity wall also started to present some problems on the south-east region of dock 1 , in an
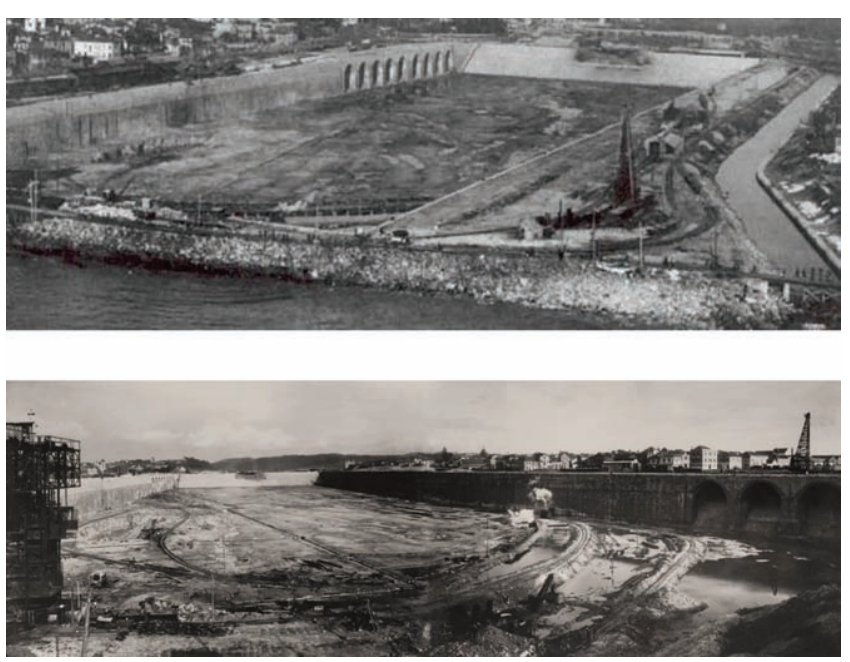

Figure 4. Construction of dock number 1

extension of $140 \mathrm{~m}$, where caverns were detected on the quay wall. This was resolved by the solution presented in Figure 7, with a sheet pile curtain and oblique ground anchors. On the north side of the dock, the rehabilitation included a $15 \mathrm{~m}$ extension of the embankment, allowing the installation of the first ro-ro terminal of Leixões.

Along with this rehabilitation, to minimise the corrosion problems on the steel sheet piles, an impressed current cathodic protection system was installed to minimise the corrosion on the main sheet pile structures and respective concrete capping beam.

Despite all the efforts made, including the protection of the ground anchors, new problems kept rising on these structures. Eventually, the problems were related with the ageing of the structures, with the increase in the loads over the quays and embankments, as well as eventual ground.

\section{Dock number 2}

With the increase in the port's operation, new quays and embankments were needed, and so dock number 2 was designed and built. Following the same line used for dock number 1, dock number 2 was also excavated inland between 1958 and 1966. The construction of the dock led to an interruption between the north and south parts of the city of Matosinhos, and so a drawbridge had to be built on a region where the bedrock was at a $-25.0 \mathrm{~m}$ ZHL depth. This location had to be maintained because it connected two important social areas of the city.

The geotechnical survey revealed two different scenarios. On the south side, good geotechnical characteristics were found, with good-quality materials, and the bedrock at less than $-11.0 \mathrm{~m}$ ZHL. On the north side, there were thick alluvial layers with poor geotechnical characteristics and a bedrock deeper than $-16.0 \mathrm{~m}$ 

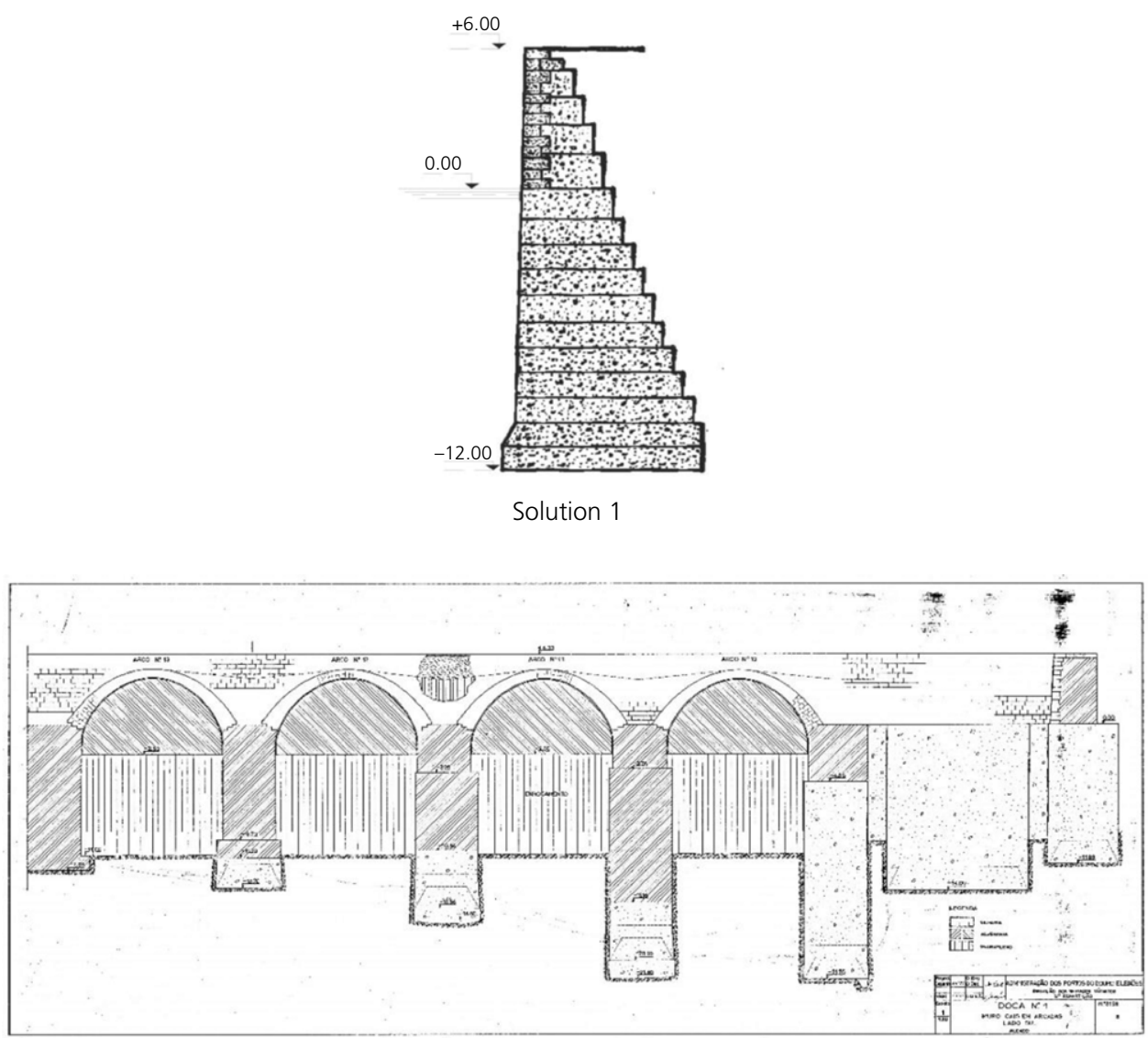

Solution 2

Figure 5. Cross-sections of the two solutions used on dock number 1 (units are in m)

ZHL, as a result of being on the natural path of the River Leça, which meanders in this region for centuries.

Following the geotechnical survey undertaken, three different solutions were defined:

- solution 1 - a gravity wall that was implemented whenever the bedrock was above $-11.0 \mathrm{~m}$ ZHL (south dock with $700 \mathrm{~m}-$ no problems registered until today)

- solution 2 - pile quay wall (no retention wall) - north-west dock $(300 \mathrm{~m})$

- solution 3 - a sheet pile quay wall with a retention wall (sheet pile curtain) - north-east dock (370 m) (Figure 8).

The pile solutions were defined where the bedrock was below $-16.0 \mathrm{~m}$ ZHL.

However, in the 1970s, significant displacements were registered on the crest of north-west quay wall beam $(300 \mathrm{~m})$, along with cracks, displacements of up to $50 \mathrm{~cm}$, settlements of up to $25 \mathrm{~cm}$ on the embankment and failure of transverse beams, which led to the inoperability of this quay wall for more than 20 years. Later analysis assumed that the failure was a consequence of a steep slope embankment under the quay (1:2.5), associated with a poor geotechnical survey. With only eight boreholes which did not anticipate the thick layers of sludge identified later, all together, they contributed to the failure of the pilled structure.

In the late 1990s, the rehabilitation of dock number 2 included the north-west and north-east quays, with a reinforcement that included transversely a set of four new piles and a slab on top that was embedded in the existing capping beam (Figure 9). No problems were identified after this rehabilitation.

\section{Dock number 4}

Dock number 4 was constructed between 1974 and 1983 and had two different structural solutions (Figure 10) based on complete geophysical and geotechnical surveys, which included sampling and laboratory tests:

- solution 1 - gravity quay wall, where the bedrock was about $-12.0 \mathrm{~m}$ ZHL (south and west quays - total of $600 \mathrm{~m}$ ) 


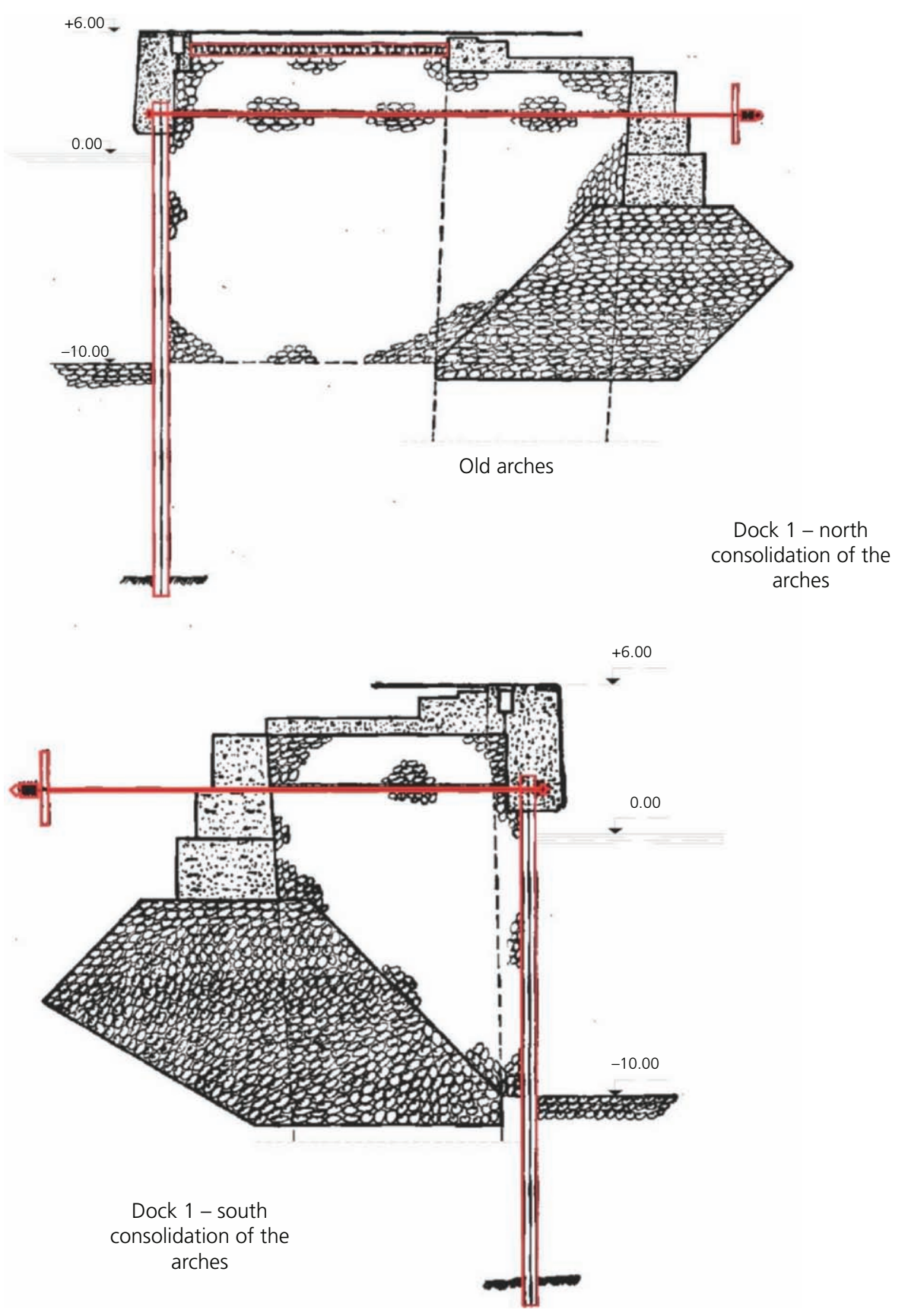

Figure 6. Rehabilitation project of dock number 1 - north and dock number 1 - south

- solution 2 - sheet pile structure quay wall where the bedrock was below $-12.0 \mathrm{~m}$ ZHL (north, east and south-east quays total of $700 \mathrm{~m})$.

The survey detected muddy layers with a thickness bigger than $25 \mathrm{~m}$ and weathered granites $\left(\mathrm{W}_{4-5}\right)$. During the construction, piles of more than $50 \mathrm{~m}$ were executed and a strong heterogeneity was observed on the bedrock depth.
Despite all the in situ studies and tests conducted, the careful monitoring of the execution process allowed the detection of an unexpected behaviour of the ground during the dredging process and the precasting of the blocks, leading to the need to rehabilitate part of the south dock (Figure 11) and also to the execution of an extra $100 \mathrm{~m}$ of reinforced pile structure quay on the south-east side of the dock, as well as the need to rehabilitate partially the foundations of the highway bridge at the east side of the dock. 
The port of Leixões (Portugal): over 120

years of knowledge

Lopes and Dias

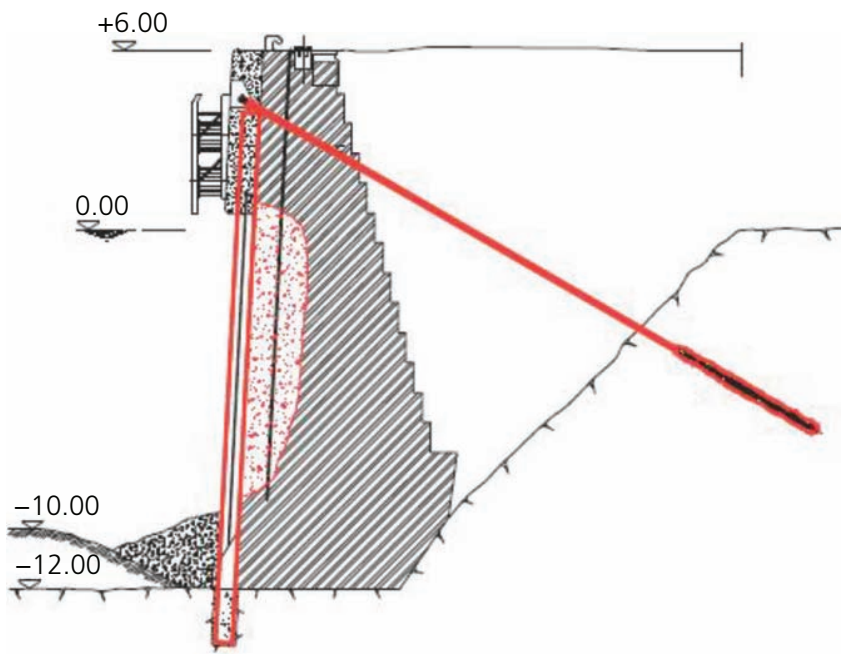

Figure 7. Rehabilitation of the gravity wall of dock number $1-$ south

\section{South container terminal}

The geology of this area of the port is characterised by the presence, at low depth, of thick layers of sludge alluvia, which occupy the fossil valley of River Leça. The results of the geotechnical survey demonstrated that those soils would most likely present strong compressibility.

The results of the geotechnical survey advised to mitigate the potential stability problem on the railway foundation by designing a pile solution reaching the bedrock.

Considering (a) the bad experience on the site where the blocks were precast, $(b)$ that the future use of the terminal would require a $5 \mathrm{t} / \mathrm{m}^{2}$ embankment and (c) that the cranes under rails would need proper stability, a detailed pre-consolidation programme was developed to anticipate the expected $+1.0 \mathrm{~m}$ settlement of the embankment, eventually asymmetric, that could damage the piles and limit the operation of the future terminal.

The development of the pre-consolidation programme included the following main objectives.

- Alluvial non-consolidated thick formations could lead to important settlements, eventually asymmetric, that would be incompatible with the normal operation of the terminal.

- Pre-consolidation of the embankment $(\bar{U}=90 \%)$ could be achieved using vertical geo-drains and temporary embankments (Figures 12 and 13).

- Design of the geo-drain grid should be defined to guarantee maximum pre-settlement in the shortest period possible.

- A monitoring programme should be designed to control the settlement process and could use different pieces of
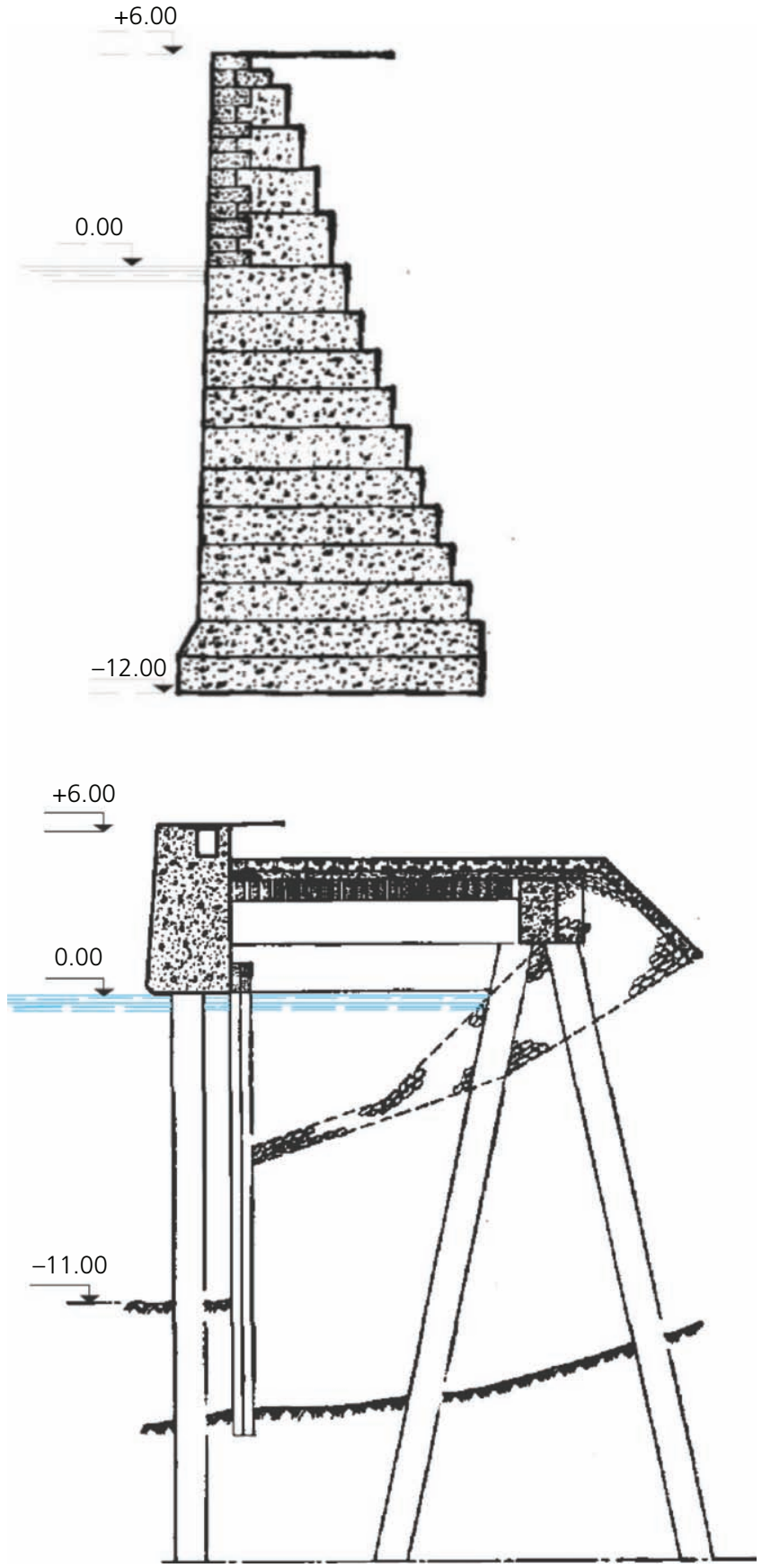

Figure 8. Cross-sections of dock number 2 quays

equipment, such as inclinometers, piezometers and levelling plates.

\section{Pre-consolidation project}

Using a Terzaghi abacus, which relates the consolidation degree $\bar{U}$ (assumed as dimensionless consolidation) with the time factor $T_{\mathrm{v}}$ and $T^{\prime}$, with the diameters ratio $n$ between diameters $D$ of the influence area of the drain, and $d$ of the own drain, the project assumed the following equations: 


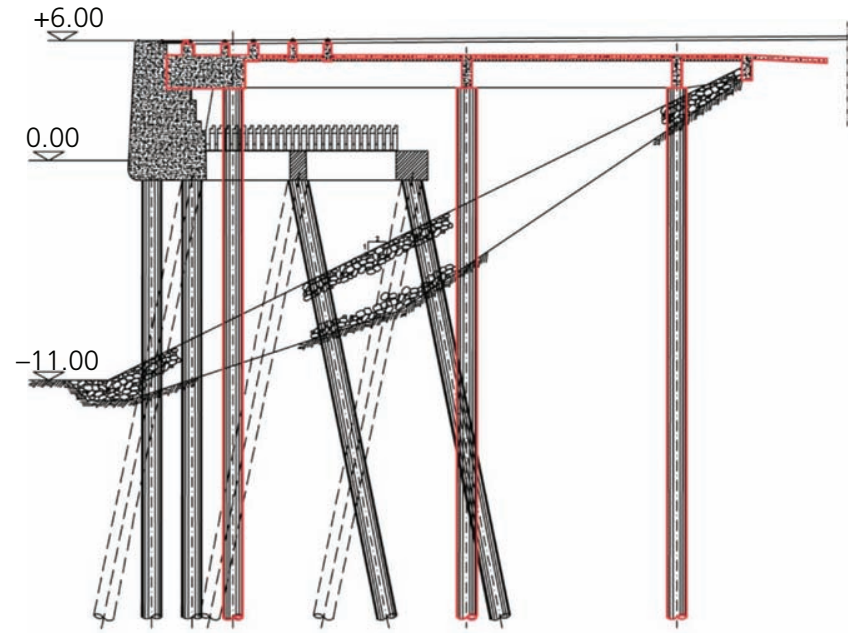

Figure 9. Rehabilitation solution applied on the dock 2 north

total settlement

1. $\Delta H=m_{\mathrm{v}} \Delta p H$

time, considering natural settlement

2. $T_{\mathrm{v}}=t \frac{C_{\mathrm{v}}}{(H / 2)^{-2}}$

- time, using the consolidation system

3. $T^{\prime}=4 C_{\mathrm{r}}\left(\frac{t}{d}\right)^{-2}$

where $\Delta H$ is the total settlement; $\Delta p$ is the effective stresses variation; $H$ is the thickness of the compressible layer; $t$ is time; $d$ is the theoretical diameter of the drain used; $T_{\mathrm{v}}$ is the time factor considering natural settlement; $T^{\prime}$ is the time factor considering the consolidation system; $m_{\mathrm{v}}$ is the volumetric compressibility coefficient; $C_{\mathrm{v}}$ is the vertical consolidation coefficient; and $C_{\mathrm{r}}$ is the radial consolidation coefficient.

The geotechnical survey included 28 cone penetration tests and 24 standard penetration tests (including vane tests) and coring for laboratory analysis (Atterberg limits, granulometry, specific weight, humidity, non-limited compression, triaxial compression and oedometer test with vertical and radial drainage). The results showed quite variable geotechnical characteristics but allowed the definition of the most probable values for the following parameters:

ast side of the embankment

$m_{\mathrm{v}}=3.0 \times 10^{-2} \mathrm{~cm}^{2} / \mathrm{kg}$
- $C_{\mathrm{v}}=4.0 \times 10^{-4} \mathrm{~cm}^{2} / \mathrm{s}$

- $C_{\mathrm{r}}=16.0 \times 10^{-4} \mathrm{~cm}^{2} / \mathrm{s}$

west side of the embankment

- $m_{\mathrm{v}}=5.0 \times 10^{-2} \mathrm{~cm}^{2} / \mathrm{kg}$

- $C_{\mathrm{v}}=2.5 \times 10^{-4} \mathrm{~cm}^{2} / \mathrm{s}$

- $C_{\mathrm{r}}=25.0 \times 10^{-4} \mathrm{~cm}^{2} / \mathrm{s}$.

The analysis of the results estimated that total settlements could be between 4 and $90 \mathrm{~cm}$ and that pre-consolidation could be achieved in 3 months, using a grid of geo-drains (Mebradrain 7404 ) with diameters ranging from 1.1 to $2.0 \mathrm{~m}$, depending on the area considered. To guarantee the desired settlement, artificial sand embankments were used $(3.0 \mathrm{~m}$ height $)$ to simulate the $5 \mathrm{t} / \mathrm{m}^{2}$ expected on the terminal operation. The remaining heights of these embankments were moved to a different location whenever $90 \%$ of the settlement was reached.

\section{Execution of the pre-consolidation project}

The geo-drains were installed using an excavator properly adapted with a guiding tower of more than $30 \mathrm{~m}$ allowing the installation of the geo-drains with the non-woven polypropylene mattress (Figure 12).

On the area of the future terminal, piezometers, levelling plates and inclinometers were installed and properly monitored during all the pre-consolidation process (Figure 14), which included also several geotechnical campaigns, before, during and after the intervention.

Good and expeditious results were guaranteed by the levelling plates, while the piezometers also had good results, but these were expensive and delayed when compared with the levelling plates, even though they are essential to validate the results of the levelling plates. Unfortunately, the inclinometers did not present feasible results, being also expensive and delayed.

\section{Beams of the crane rails}

As previously referred, due to geotechnical fragilities, the beams that support the railways were founded over piles with an $800 \mathrm{~mm}$ diameter, using Benoto EDF 1180 equipment, except for the seaside rails that were directly supported by the capping beam of the quays. Those piles were executed after pre-consolidation had been achieved, in order to avoid horizontal movements of the soils that could damage the piles.

During the last 30 years of service of the container terminal, some displacements were registered on the gravity quay wall, inducing changes on the rail gauge, leading to the need for stabilisation and correction works.

\section{Final remarks}

The port of Leixões has completed 125 years of existence in the year 2018, an artificial port that covered $2 \mathrm{~km}$ of the ocean and more than $3 \mathrm{~km}$ inland (Figure 15). This work focused mainly on the inland 
Geotechnical Research

Volume 8 Issue 2
The port of Leixões (Portugal): over 120

years of knowledge

Lopes and Dias
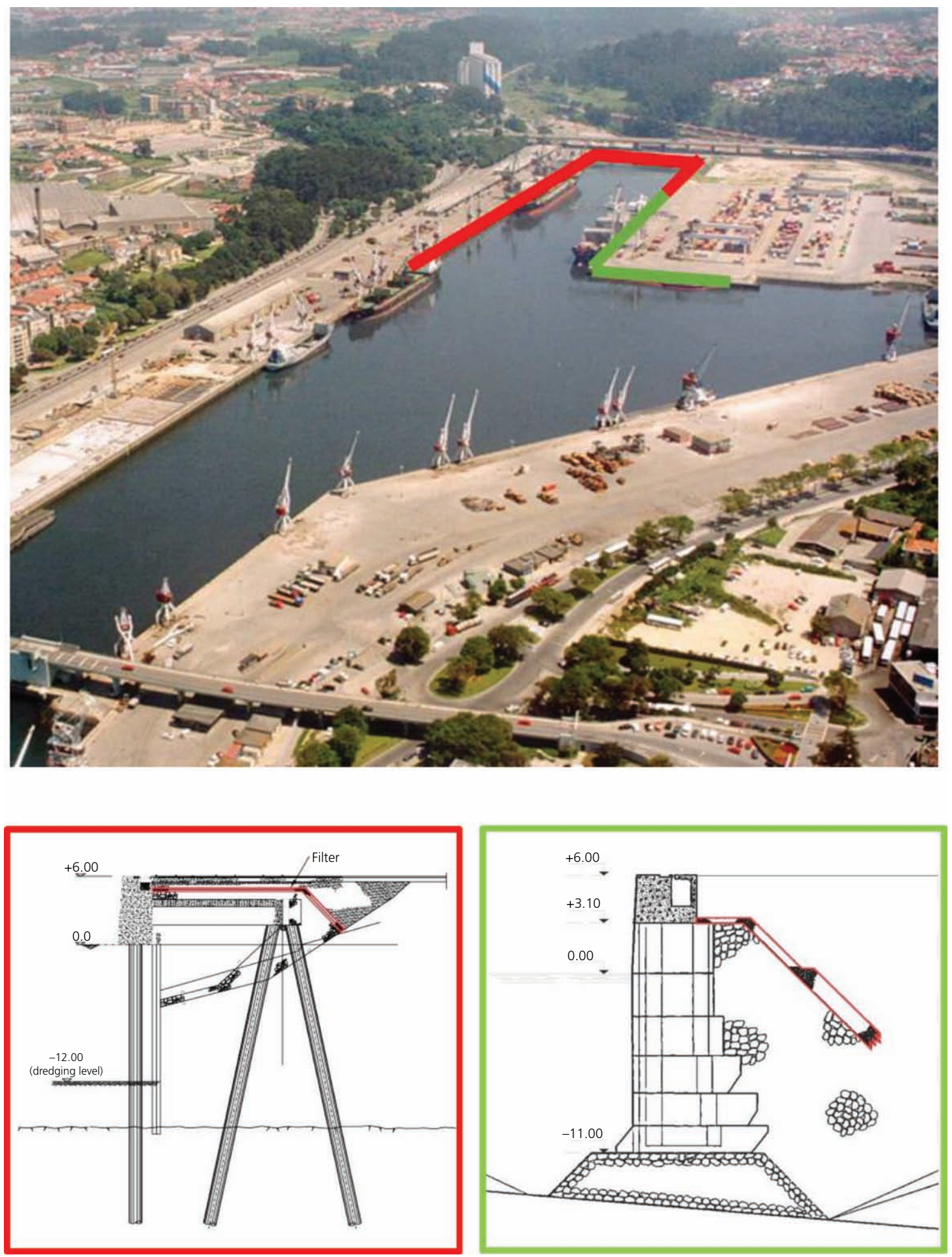

Figure 10. Aerial view and cross-sections of the dock number 4 quays 
The port of Leixões (Portugal): over 120 years of knowledge

Lopes and Dias

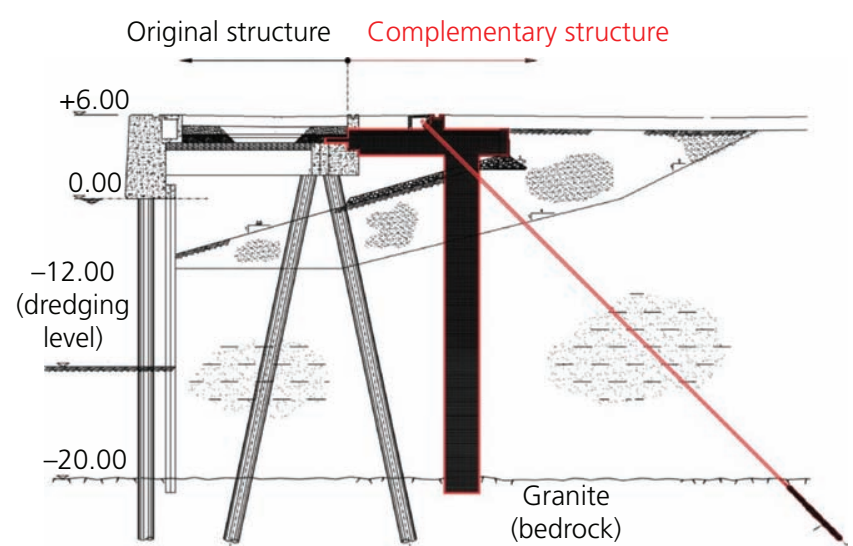

Figure 11. Rehabilitation of first $100 \mathrm{~m}$ of the south-east quay of dock number 4
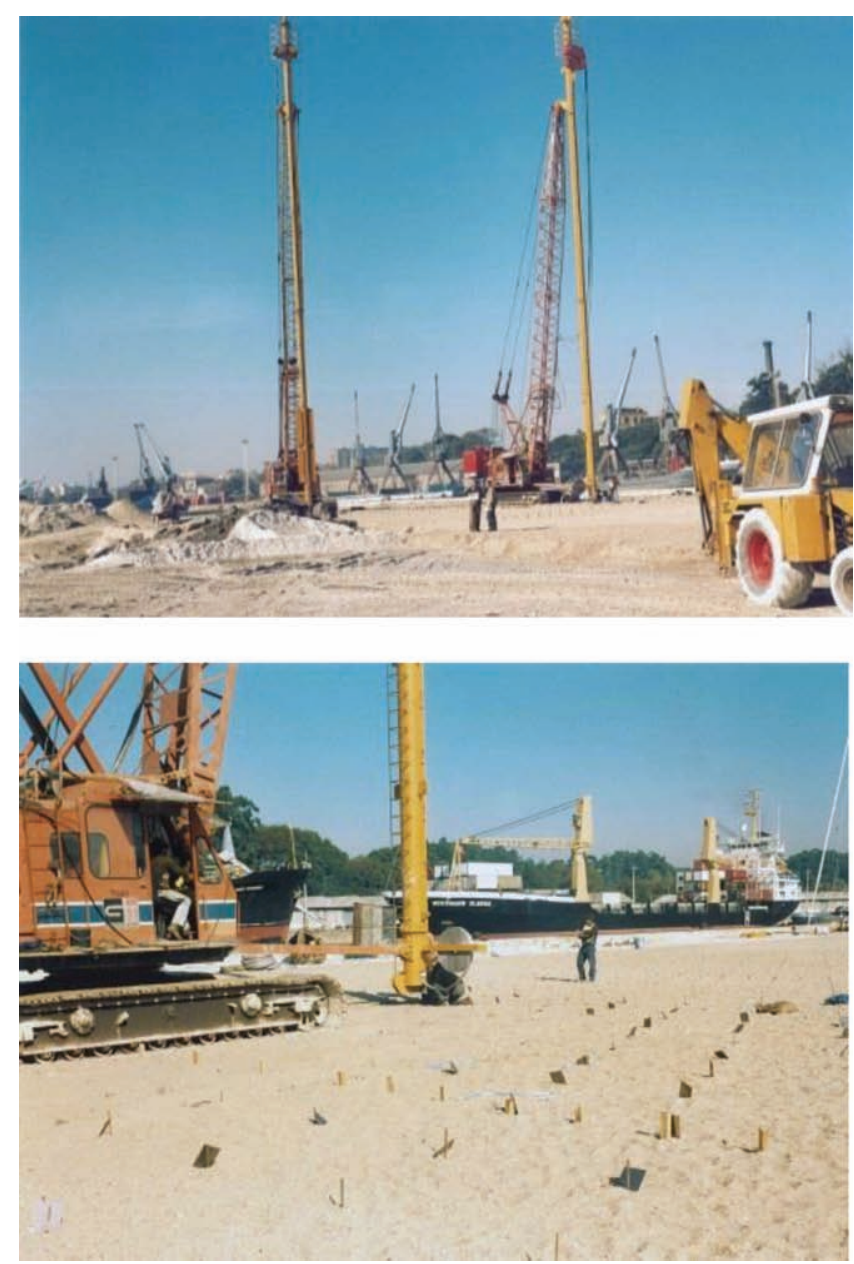

Figure 12. Excavators, guiding towers and geo-drains installed

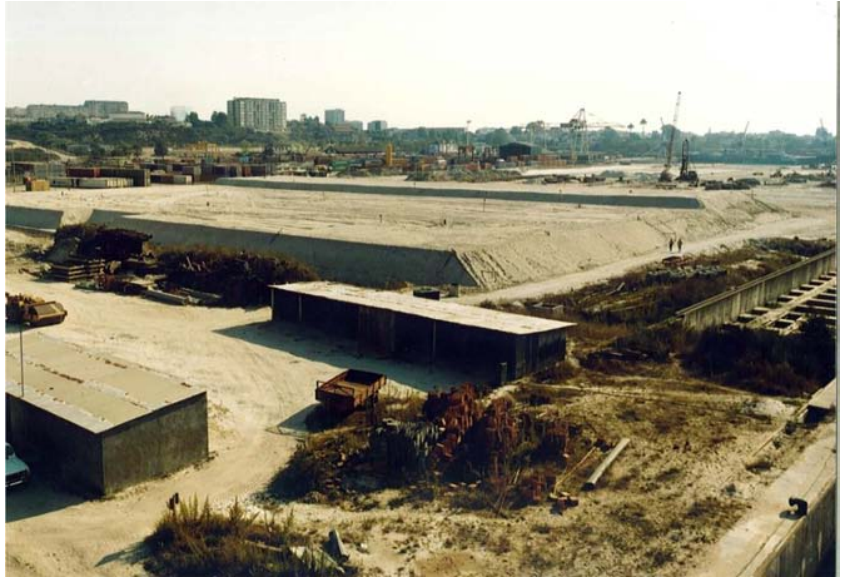

Figure 13. Artificial embankments used

stretch where most of the geotechnical problems arise. Through the years, a strong effort was accomplished regarding the monitoring and survey of the port structures before, during and after the interventions, but there were always issues that were not anticipated. For that reason, the port of Leixões confirms the importance of continuing the research and development of innovative processes to improve knowledge in this significant emerging field of harbour and marine geotechnics. However, it is vital never to forget the history of the design, project and works related to the harbour evolution. The construction of the quays and embankments over the fossil valley (in a geological sense) of the River Leça strongly contributed to the problems that were registered over the years on the port. In fact, important harbour geotechnical knowledge of the port of Leixões has been attained through the years. Besides, the port of Leixões advances in a keen way with technological and knowledge achievements, and a key thought could be highlighted: 'We cannot fight nature; we should live with it', or in the impressive words of McHarg (1992), engineers should 'design with nature'.

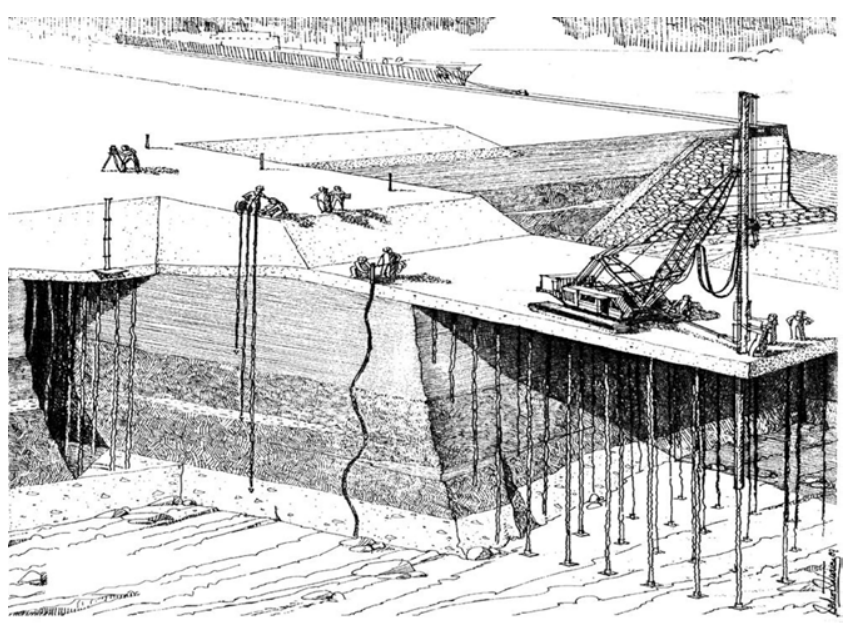

Figure 14. Pre-consolidation works and monitoring systems 


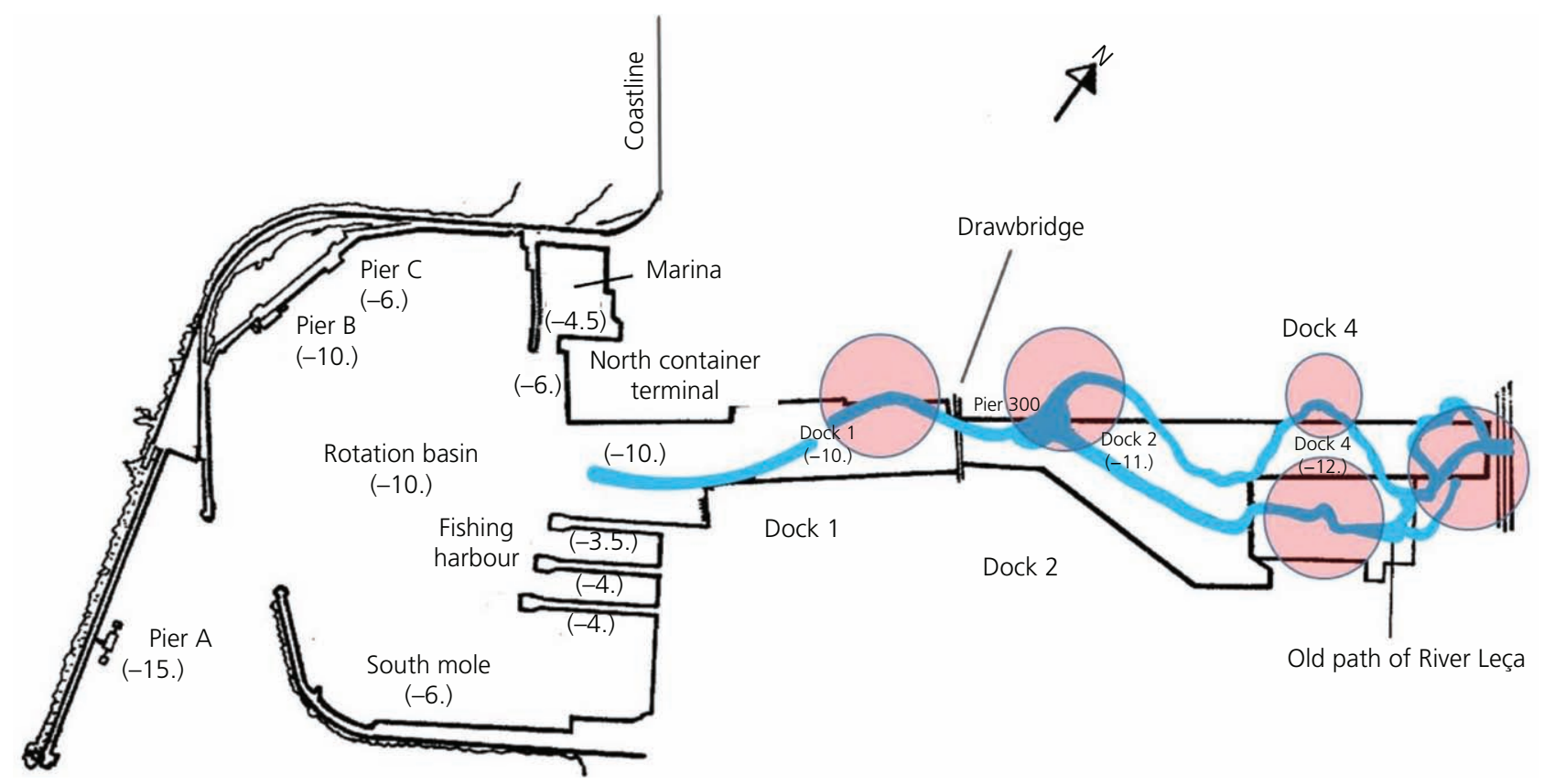

Figure 15. The port of Leixões and the old fossil valley of River Leça

\section{REFERENCES}

Alves JF and Brògueira-Dias E (2001) O fio de água: o porto e as obras portuárias (Douro-Leixões). História, Revista da Faculdade de Letras, Universidade do Porto 2(III Série): 93-106 (in Portuguese).

APDL (Port Authority of Douro, Leixões and Viana do Castelo) (1987) Terminal de Contentores TC4S - $1^{a}$ Fase - Nota Descritiva dos Trabalhos em Curso. APDL, Leça da Palmeira, Portugal (in Portuguese).

Brògueira-Dias E (1992) Port of Leixões: significance of geological conditions in dock construction. A Geotecnia no Mundo Técnico: Problemas Concretos Surgidos em Obra. APDL, Leça da Palmeira, Portugal (in Portuguese).

Brògueira-Dias E and Alves JF (2010) Ports, policies and interventions in ports in Portugal - 20th Century. Cahiers de la Méditerranée 80: 41-64.

Brògueira-Dias E and Coutinho A (1998) Dragagens no Porto de Leixões e Barra do Douro (Década de 90) e alimentação artificial da faixa costeira adjacente. Iniciativa Eurocoast, Dragagens, Dragados e Ambientes Costeiros, Lisboa, Portugal, pp. 123-133 (in Portuguese).

Ciria (Construction Industry Research and Information Association), CUR (Centre for Civil Engineering) and Cetmef (Centre d'Etudes Techniques Maritimes Et Fluviales) (2007) The Rock Manual: The Use of Rock in Hydraulic Engineering, 2nd edn. Ciria-Centre for Civil Engineering Research, London, UK, C683.

Coelho C, Silva R, Veloso-Gomes F and Taveira-Pinto F (2009) Potential effects of climate change on northwest Portuguese coastal zones. ICES Journal of Marine Science 66(7): 1497-1507.

Dias JMA, Boski T, Rodrigues A and Magalhães F (2000) Coast line evolution in Portugal since the Last Glacial Maximum until present: a synthesis. Marine Geology 170(1): 177-186.

Gomes A, Ramos-Pereira A, Araújo MA, Sousa A and Veloso-Gomes F (2005) Douro's estuary dynamics. In Portugal: Coastal Dynamics Field Trip Guide A1, Sixth International Conference of the IAG (Ramos-Pereira A, Trindade J and Neves M (eds)). Universidad de Zaragoza, Zaragoza, Spain, pp. 11-15.
Lopes HG (2013) Experimental Analysis of the Interaction between Waves and a Rubble-mound Breakwater Protected by a Detached Breakwater, Using Video Imagery Techniques. The Port of Leixões Case. PhD thesis, University of Porto, Porto, Portugal. See https://repositorio-aberto.up.pt/handle/10216/73972 (accessed 27/02/2021).

Lopes HG, Taveira-Pinto F, Veloso-Gomes F et al. (2013) Application of image processing tools on physical model tests. Proceedings of the 6th SCACR - International Short Course/Conference on Applied Coastal Research, Lisbon, Portugal, CD-ROM.

McHarg IL (1992) Design with Nature, 25th anniversary edn. Wiley, New York, NY, USA.

Mota-Oliveira IB, Valle AJSF and Miranda FCC (1982) Littoral problems in the Portuguese west coast. In Coastal Engineering 1982 (Edge BL (ed.)). American Society of Civil Engineers, Reston, VA, USA, pp. 1951-1969.

Mota-Oliveira IB, Trigo Teixeira A and Sanches do Valle A (2000) West coast of Portugal (Espinho): a comparision between project predictions and reality. In Coastal Engineering 2000 (Edge BL (ed.)). American Society of Civil Engineers, Reston, VA, USA, pp. 3552-3565.

Pérez-Alberti A, Pires A, Freitas L and Chaminé HI (2013) Shoreline change mapping along the coast of Galicia. Proceedings of the Institution of Civil Engineers - Maritime Engineering 166(3): 125-144, https://doi.org/10.1680/maen.2012.23.

Pinto A, Pita X, Neves M and Vaz J (2013) Unusual geotechnical solutions at the Leixões Cruise Terminal. In Proceedings of the 18th International Conference on Soil Mechanics and Geotechnical Engineering, Paris (Delage P, Desrues J, Frank R, Puech A and Schlosser F (eds)). Presses des Ponts, Paris, France, pp. 2075-2078.

Pires A, Chaminé HI, Piqueiro F and Rocha F (2014) Coastal geoengineering techniques for the assessment of rock armour structures. Marine Georesources \& Geotechnology 32(2): 155-178, https://doi. org/10.1080/1064119X.2012.728684. 
Geotechnical Research

Volume 8 Issue 2
The port of Leixões (Portugal): over 120

years of knowledge

Lopes and Dias
Pires A, Chaminé HI, Piqueiro F, Pérez-Alberti A and Rocha F (2016) Combining coastal geoscience mapping and photogrammetric surveying in maritime environments (Northwestern Iberian Peninsula): focus on methodology. Environmental Earth Sciences 75: article 196.

Rosa-Santos PJ and Taveira-Pinto F (2013) Experimental study of solutions to reduce downtime problems in ocean facing ports: the Port of Leixões, Portugal, case study. Journal of Applied Water Engineering and Research 1(1): 80-90.

Sousa F and Alves J (2002) Leixões: Uma História Portuária. APDL, Leça da Palmeira, Portugal (in Portuguese).
Veloso-Gomes F and Taveira-Pinto F (2003) Portuguese coastal zones and the new coastal management plans. Journal of Coastal Conservation 9(1): 25-34.

Veloso-Gomes F, Taveira-Pinto F, Neves L, Barbosa JP and Coelho C (2004) Erosion risk levels in the NW Portuguese coast: the Douro mouth Cape Mondego stretch. Journal of Coastal Conservation 10(1): 43-52.

Veloso-Gomes F, Taveira-Pinto F, Lopes HG and Brògueira-Dias E (2009) Overtopping on breakwaters of complex cross sections. In Coastal Structures 2007: Proceedings of the 5th International Conference (Franco L, Tomasicchio GR and Lamberti A (eds)). World Scientific, Singapore, pp. 1596-1607.

\section{How can you contribute?}

To discuss this paper, please submit up to 500 words to the editor at journals@ice.org.uk. Your contribution will be forwarded to the author(s) for a reply and, if considered appropriate by the editorial board, it will be published as a discussion in a future issue of the journal. 